\title{
Spatial Distribution of Plankton in Response to Ecological Dynamics in Tropical Shallow Lakes: Insight from Lake Malombe, Malawi
}

RODGERS MAKWINJA ( $\nabla$ rodgers.makwinja@aau.edu.et)

Addis Ababa University https://orcid.org/0000-0002-0818-4727

Seyoum Mengistou

Addis Ababa University

Emmanuel Kaunda

Lilongwe University of Agriculture and Natural Resources

Tena Alemiew

Addis Ababa University

\section{Research Article}

Keywords: Chlorophyll a, Physical-chemical variables, Phytoplankton, Zooplankton group

Posted Date: March 30th, 2021

DOl: https://doi.org/10.21203/rs.3.rs-338360/v1

License: (c) (i) This work is licensed under a Creative Commons Attribution 4.0 International License. Read Full License 


\section{Abstract}

This study assessed plankton density and biomass in an attempt to better understand their spatial and seasonal variation in Lake Malombe. Samples were collected for analysis during the hot dry season (HDS) and cool dry windy season (CDWS). The zooplankton identified were T. cunningtoni (TC), $M$. aEq. Aequatorialis (MAA), T. neglectus (TN), Bosmina longirostris (BL), Diaphanosoma spp (DS), Nauplii, and Rotifer. These zooplankton groups belong to copepods, Cyclopidae, Cladocera, Ctenopod, and Rotifers. The phytoplankton biomass exhibited a strong seasonal variation with the highest value observed in HDS and lowest in CDWS. Zooplankton such as T. cunningtoni, M. aEq. Aequatorialis, T. neglectus, Bosmina longirostris, Diaphanosoma spp, Nauplii, and Rotifer were dominant during the HDS. The $\mathrm{WT}, \mathrm{pH}$, and $\mathrm{DO}$, Chlo-a positively correlated with all zooplankton groups. The $\mathrm{Na}^{+}$and $\mathrm{K}^{+}$positively correlated with TC, MAA, DS, Nauplii, and Rotifers. The $\mathrm{Cl}^{-}$positively correlated with DS, Rotifers while, $\mathrm{CO}_{3}{ }^{2-}$ positively correlated with TC. $\mathrm{HCO}^{3-}$ correlated with DS and Rotifers positively while TDS correlated with BL, Nauplii, and Rotifers negatively. Nitrite affected all zooplankton groups negatively while SRP had a positive effect on all zooplankton density. The study revealed that physical-chemical variables, some major ions, and Chlo-a are the most important factors influencing the spatial and seasonal variation of zooplankton density in the lake. These findings demonstrate the interaction between physical-chemical variables, phytoplankton, and zooplankton and highlight the significance of ecological understanding of the complex dynamics of food web system in tropical shallow lakes - under the changing climate.

\section{Introduction}

Inland tropical African Rift Valley lakes are characterized by carbonate salts concentration and are often described as alkaline lakes. These lakes often lack connection to the marine environment and hence some of them are described as freshwater lakes (Schagerl \& Oduor, 2008). They possess tremendous ecological values to the local communities in terms of provisioning, regulatory, supporting, cultural and aesthetic services. They are also best known for having the world's richest lacustrine fish fauna and the family of Cichlidae which provide the supreme example of geographically circumscribed vertebrate evolution and a unique comparative series of natural laboratories for evolutionary studies (Coulter, et al., 1986). Despite the ecological importance of these lakes, studies focusing on plankton species distribution and how they are affected by seasonal dynamics of physical-chemical variables are very scant (Ndebele-Murisa et al. 2010; Tilahun \& Ahlgren, 2010; Gebrehiwot et al. 2017; Ma et al. 2019). Several ecological factors such as WT, EC, nutrient loadings, calcium ions, magnesium ions, and hydrological pattern have been considered as critical factors responsible for shaping the biological composition and distribution of plankton in inland lakes (Ha et al. 1998; Teubner, 2003; Afonina \& Tashlykova, 2018; Hamid et al. 2020). In regions where seasonality is very distinct, variation in environmental factors plays a major role in plankton composition and distribution via the influence of light and nutrients concentrations (Liu et al. 2010; Vidal et al. 2017). Different researchers have extensively studied the plankton composition and structure in both freshwater and marine environment 
(Boyce et al. 2010; Borics et al. 2021; Murphy et al. 2020). These researchers have concluded that the dynamic changes of plankton in terms of genera richness, diversity, and density are instigated by the ecological changes of the lake.

In Malawi, Lake Malombe also described as a permanent floodplain lake is located in the Upper Shire River Basin in the outlet of Lake Malawi in Mangochi District (Malawi Government, 2013). The Upper Shire River Basin lies entirely within the Great African Rift Valley system and is characterized by a series of major and minor faults. It is the largest in Malawi and the fourth-largest in Africa. Lake Malombe is fed by water from Lake Malawi through an 18km stretch of the Upper Shire River basin. The Lake shares important unique aquatic ecology with Lake Malawi which includes rich fish biodiversity, endemism, and genetic plasticity. Unlike Lake Malawi, Lake Malombe is a shallow, turbid, and nutrient-rich lake, with shelving vegetated shores. It is designated as the most productive Lake in Africa (Tweddle et al. 1995) due to its enriched waters from inflowing streams originating from highly populated catchment areas and by recycling of nutrients in the sediments due to its shallow depth. Plankton forms an essential component of the aquatic food web in this lake. Lake Malombe has been extensively studied since the 1960s by biologists, hydrologists, and ecologists (Hara, 2006; Tweddle et al 1995; Anseeuw et al. 2011; Jambo \& Hecht 2001; Jamu, et al 2011; Hara \& Njaya 2016; Makwinja et al. 2021). However, a few studies about the temporal and spatial distribution of plankton in this lake are published (Dulanya, et al. 2014). Information about the spatial distribution of plankton in response to ecological dynamics in this lake is still lacking. Therefore, the main objectives of this paper are: (i) to assess the distribution and abundance of zoo-phytoplankton in a different transect of the lake and (ii) determine the influence of the physical-chemical variables and phytoplankton biomass on zooplankton density in the lake. Attempts are made to answer the following questions: Is there any spatial variation in phytoplankton density and zooplankton taxa, predominately between the middle, inlet, outlet, eastern part, and western part of the lake? Is there any seasonal variation in phytoplankton biomass and zooplankton density in Lake Malombe? Which physical-chemical variables influence the spatial and seasonal variation of zooplankton density in the lake? The findings in this study are important for the management of Lake Malombe and other tropical inland shallow lakes with similar attributes across the globe. The knowledge generated from this study is critical in fishery management and understanding the ecological balance of tropical inland lakes.

\section{Materials And Methods}

\section{Study area}

Lake Malombe is approximately $470 \mathrm{~m}$ asl and is situated between latitude $14^{0} 30^{\prime} \mathrm{S}$ and $14^{\circ} 45^{\prime} \mathrm{S}$ and longitude $35^{0} 12^{\prime} \mathrm{E}$ to $35^{0} 20^{\prime} \mathrm{E}$ (Figure 1). It is part of the Great Rift Valley system and is the third-largest lake in Malawi, $30 \mathrm{~km}$ in length and $15 \mathrm{~km}$ in width, with a total area of $420 \mathrm{~km}^{2}$, an average depth of around $2-2.5 \mathrm{~m}$, and a maximum depth of $6 \mathrm{~m}$. It lies in a broken depression running northwest from Lake Chilwa to Lake Malawi, parallel to the Shire Rift Valley. Lake Malombe catchment experiences a warm tropical climate with seasonal air temperatures ranging from $27-30^{\circ} \mathrm{C}$ degrees Celsius and an average 
annual rainfall of $691.675 \mathrm{~mm}$. In exceptional instances, temperatures go as high as 40 degrees Celsius. The lowest temperatures are experienced in May, June, and July while the highest temperatures are registered between October and November. Lake Malombe population within a $10 \mathrm{~km}$ radius is estimated at 64,000 households of which $80 \%$ of the population are predominately fishers. The upland catchment of Lake Malombe is dominated by maize cultivation, which covers $90 \%$ of arable land while rice is commonly grown in the lowland areas of the lake. Lake Malombe is an important ecosystem both local and international since it has a rich fish biological diversity that is a source of food and income to the local population and it is an important foraging ground for migrating birds. Sampling sites were selected taking into account the viability of approaching and maximum representation of the lake. The selected sites included five transects (Inlet, Western, Eastern, Middle, and Outlet) of the Lake (Figure 1). Each transect had twenty sampling points selected randomly.

\section{Sample collection and laboratory analysis}

Water samples were collected in the cool windy dry season (May to July) and hot dry season (September to November) from the georeferenced sampling sites inside the lake (Figure 1). Sampling was not conducted during the rainy season due to safety reasons. Water temperature, $\mathrm{pH}$, electrical conductivity, and dissolved oxygen were measured on-site using WTW MultiLine P4 multi-parameter probe, model (Multi 3430). Turbidity (NTU) was measured using Secchi disk (or Secchi disc). Phosphate, nitrate, and sulfate ( , , ), were determined using UV/Visible spectrophotometer (model T90) following Molybdenum blue method in conjunction with Ultraviolet Spectrophotometry for and, Turbidimetric method for Cation $\left(\mathrm{Mg}^{2+}, \mathrm{Na}^{+}, \mathrm{Ca}^{2+}, \mathrm{K}^{+}\right)$and anions $\left(\mathrm{Cl}^{-}, \mathrm{HCO}_{3}{ }^{-}, \mathrm{CO}_{3}{ }^{2-}\right)$ were determined using an Electric auto titrator (model \#775) following Microwave plasma atomic emission spectrophotometry technique (APHA, 1998 ). For quality control, the charge balance of major ions for all water samples was done using the following equation:

Ionic charge balance $($ meq $/ L)=\frac{\left.\left[\sum \text { (anions }\right)-\sum(\text { cations })\right]}{\left[\sum(\text { anions })+\sum(\text { cations })\right]}$

The final charge units for cations and anions were expressed in meq/L (milli-equivalents per liter). Turbidity (NTU) was measured by Secchi disk (SD) (Naumenko, 2008).

\section{Sampling and determination of chlorophyll-a}

Water samples were collected using five automatic ISCO samplers (Teledyne Isco, Lincoln, NE, USA) (one at each sampling transect). The average sampling depth of the inlet was $3.8 \mathrm{~m}$, eastern part $2 \mathrm{~m}$, western part $2 \mathrm{~m}$, middle $3.8 \mathrm{~m}$, and outlet $2.8 \mathrm{~m}$. The sampling points were done on the shores of the lake except those collected from the inlet, outlet, and middle. A total of 300 samples $(500 \mathrm{ml}$ each) were collected from the sampling sections during the HDS and the CDWS with 150 samples collected from each season. Water samples were preserved in a cooler box at $-4^{\circ} \mathrm{C}$ and transported to the laboratory for analysis. In the laboratory, the water samples were filtered using a Whatman GF/C filter type, $25 \mathrm{~mm}$ in diameter at a 
residual pressure of 0.7 bar. Any visible zooplankton from the filter was removed from using forceps. The filter was then folded together with algae inside, blotted with absorbent paper to remove most of the water, and then placed in a properly labeled clean container. The filter was then placed under cold conditions (in the freezer at $-20^{\circ} \mathrm{C}$ ) for 24 hours. Before measurements, the extracts were mixed thoroughly and centrifuged for about 10 minutes at $500^{\star} \mathrm{g}$ (where $\mathrm{g}$ is gravitation acceleration $(\mathrm{g}=9.81 \mathrm{~ms}$ $\left.{ }^{2}\right)$ ). Filter fluorometer with an excitation wavelength of $430 \mathrm{~nm}$ (10 $\mathrm{nm}$ bandwidth) and the emission wavelength of $680 \mathrm{~nm}$ (10nm bandwidth) was used to determine chlorophyll a. The fluorometer was calibrated first using a commercial solution of pure chlorophyll manufactured by Sigma, UK. The concentration of the solution (in $90 \%$ acetone) was determined spectrophotometrically using an extinction coefficient of $87.67 \mathrm{gg}^{-1}$ (Jeffrey \& Humphrey, 1975) at $664 \mathrm{~nm}$ against a $90 \%$ acetone blank. The calibration was carried out with different chlorophyll-a concentrations covering all the linear ranges for the relationship between chlorophyll concentration and instrument output. Also, the maximum acid ratio was determined by measuring the fluorescence of the standard before and after acidification. The sample extracts from the centrifuge tubes were then transferred to the fluorometer cuvette by carefully pipetting and then measured against a $90 \%$ acetone blank. $0.2 \mathrm{ml} 1 \% \mathrm{v} / \mathrm{v}$ hydrochloric acid was added in the corvette, mixed properly, left for 2-5 minutes, and then measured again against a $90 \%$ acetone blank. Chlorophyll-a was determined according to the equation of Holm-Hansen et al. (1965).

$$
\text { Chlorophyll a }\left(\mathrm{mg} / \mathrm{m}^{3}\right)=K *\left(F_{m} /\left(F_{m}-1\right)\right) * V_{e} *\left(F_{0}-F_{a}\right) / V_{f}
$$

Where: $\mathrm{k}=$ calibration coefficient $=\mu \mathrm{g} \mathrm{Chl}$ a per $\mathrm{ml} 90 \%$ acetone per instrument fluorescence units, $F_{m}=$ maximum acid ratio $\left(F_{0} / F_{a}\right.$ of pure chlorophyll a standard, $F_{0}=$ sample fluorescence before acidification, $F_{a}$ is sample fluorescence after acidification and $V_{e}$ is extraction volume (ml), $V_{f}$ is a filtered volume (L).

\section{Determination of zooplankton}

A clear plastic box was lowered in the water column at a discrete depth (the inlet $3.8 \mathrm{~m}$, eastern part $2 \mathrm{~m}$, western part $2 \mathrm{~m}$, middle $3.8 \mathrm{~m}$, and outlet $2.8 \mathrm{~m}$ ) and raised to trap the zooplankton inside the box. The water was allowed to exit a small mesh net (70-100 $\mu \mathrm{m}$ mesh size) attached to the lower wall of the box and zooplankton was collected inside a sampling bottle at the end of the net. Three sample replicates were collected at each sampling station. The water samples were preserved with a $5 \%$ buffered formaldehyde solution and kept in a cooler box at low temperature before taken into the laboratory for analysis. The samples were properly labeled using waterproof permanent Blank India ink. The sampling period was between October and November (HDS) and between May and June (CDS). Sampling activities were replicated three times per season. In the laboratory, the sample was drained of excess formaldehyde. For small zooplankton, such as rotifers, nauplii, which occur at high densities $(>1000$ per liter), $100 \mathrm{ml}$ concentrated samples were decanted using a hand pipette and reduced to $5 \mathrm{ml}$ for microscopic viewing. The pipette was rinsed with distilled water into a culture dish to remove any adherent organisms. The known percentage of the sample volume at high magnification multiply by total volume and divide by counted volume was done to obtain the total number of animals in the sample. The identification of zooplankton was done at the lowest possible taxonomic level following standard 
taxonomic references (Fernando, 2002; Shiel, 1995) and observed morphometric features using a calibrated compound light microscope (Max II 1202.4000 model) fitted with an ocular micrometer. For large zooplankton such as Diaphanosoma spinulosum, which occurs at relatively low densities (1 to 100 per liter), the whole sample was scanned at low magnification, counting all observed individuals. The zooplankton density in the lake was estimated by dividing the volume of water filtered with the trap by the number of animals of each species.

\section{Data analysis}

Statistical analysis was done using SPSS 20 and Microsoft Excel windows 2016. Before analysis, the physical-chemical variables (except $\mathrm{pH}$ ), the biomass of phytoplankton, and zooplankton density were log-transformed to achieve homoscedasticity. The differences of physical-chemical variables, phytoplankton biomass, and zooplankton density were analyzed in different seasons using paired t-test. Relationships between phytoplankton biomass, zooplankton density, and physical-chemical variables were analyzed using the Canonical Correspondence Analysis (CCA). Pearson correlation analysis was done to confirm the significant relationship between physical-chemical variables, the biomass of phytoplankton, and the zooplankton density.

\section{Results And Discussion}

The majority of the Lake Malombe local population depends on unprotected water from the lake (Kalumbi et al. 2020). In the upper catchment of the lake, water from rivers that drain into the lake is heavily contaminated with agricultural chemicals such as inorganic fertilizers, insecticides, and other human contaminants although studies focusing on the limnological status of these rivers are scarcely available. Over $90 \%$ of the local population further depends on the fishery as the main source of livelihood. This study used nutrient loading (nitrite, SRP, and sulfate), major cations and anions ( $\mathrm{Ca}^{2+}$, $\left.\mathrm{Na}^{+}, \mathrm{Mg}^{2+}<\mathrm{K}^{+}, \mathrm{HCO}_{3}{ }^{-}, \mathrm{Cl}^{-}, \mathrm{CO}_{3}{ }^{2-}\right), \mathrm{pH}, \mathrm{WT}, \mathrm{DO}, \mathrm{EC}, \mathrm{TDS}$, Turbidity (NTU), and Chlo-a as an indicator of the ecological status that influences the spatial and seasonal distribution of zooplankton density in this lake. The $\mathrm{pH}$ plays a significant role in explaining the chemical speciation, dissolution, and precipitation (Blum \& Lasaga, 1991). The decrease in $\mathrm{pH}$ is an indicator of increased metal dissolution in the lake and a high probability of bioavailability and toxicity to humans and aquatic biota (Magalhães et al. 2015). In this study, the increase in carbon dioxide lowered the $\mathrm{pH}$ during the CDWS because carbon dioxide reacts with water to produce carbonic acid. The high rate of respiration and fewer photosynthesis activities during the CDWS resulted in low dissolved oxygen and more $\mathrm{CO}_{2}$ produced which eventually lowers $\mathrm{pH}$. The lake inlet recorded the highest $\mathrm{pH}$ during the CDWS while the eastern section of the lake recorded the highest during the HDS (Fig. 2). The values of $\mathrm{pH}$ measured in this study were in the side of alkaline with seasonal variations and were within recommended values for a healthy freshwater aquatic ecosystem (WHO, 2011; EPA, 1976; United Nations, 1992). Lake Malombe is one of the climate-sensitive lakes due to its shallowness. Climate variability has a significant effect on the behavior of the lake. Water temperatures vary with seasons and in different parts of the lake (Fig. 2). The highest WT was recorded 
at the inlet both during the CDWS and HDS. The water temperature, $\mathrm{pH}$, and $\mathrm{DO}$ had negative mean paired differences and were significantly $(p<0.05)$ higher during the HDS than the CDWS (Table 2$)$.

Table 2

Paired sample t-test of Lake Malombe physical-chemical variables and Chlo-a during CDWS and HDS

\begin{tabular}{|c|c|c|c|c|c|}
\hline Parameters & $\begin{array}{l}\text { Mean Paired } \\
\text { Differences }\end{array}$ & $\begin{array}{l}\text { Std. } \\
\text { Deviation }\end{array}$ & $\begin{array}{l}\text { Std. Error } \\
\text { Mean }\end{array}$ & t.value & p.value \\
\hline $\mathrm{Ca}^{2+}(\mathrm{CDWS})-\mathrm{Ca}^{2+}(\mathrm{HDS})$ & -0.369 & 2.976 & 0.825 & -0.447 & $0.663^{\text {ns }}$ \\
\hline $\mathrm{Mg}^{2+}(\mathrm{CDWS})-\mathrm{Mg}^{2+}(\mathrm{HDS})$ & -0.674 & 1.987 & 0.551 & -1.222 & $0.245^{\mathrm{ns}}$ \\
\hline $\mathrm{Na}^{+}(\mathrm{CDWS})-\mathrm{Na}^{+}(\mathrm{HDS})$ & -4.847 & 3.334 & 0.925 & -5.242 & $0.000^{\star *}$ \\
\hline $\mathrm{K}^{+}(\mathrm{CDWS})-\mathrm{K}^{+}(\mathrm{HDS})$ & -1.779 & 1.207 & 0.335 & -5.315 & $0.000^{\star *}$ \\
\hline $\mathrm{Cl}^{-}(\mathrm{CDWS})-\mathrm{Cl}^{-}(\mathrm{HDS})$ & -17.582 & 10.133 & 2.810 & -6.256 & $0.000 * *$ \\
\hline $\mathrm{CO}_{3}{ }^{2-}(\mathrm{CDWS})-\mathrm{CO}_{3}{ }^{2-}(\mathrm{HDS})$ & 118.397 & 13.007 & 3.607 & 32.820 & $0.000^{\star *}$ \\
\hline $\begin{array}{l}\mathrm{HCO}_{3}^{-}(\mathrm{CDWS})-\mathrm{HCO}_{3}^{-} \\
(\mathrm{HDS})\end{array}$ & 1.094 & 23.153 & 6.421 & 0.170 & $0.868^{\mathrm{ns}}$ \\
\hline $\begin{array}{l}\text { Nitrite (CDWS) - Nitrite } \\
\text { (HDS) }\end{array}$ & -0.576 & 0.266 & 0.074 & -7.822 & $0.000 * *$ \\
\hline $\begin{array}{l}\text { Sulfate (CDWS)- Sulfate } \\
\text { (HDS) }\end{array}$ & 0.077 & 1.272 & 0.353 & 0.218 & $0.831^{\mathrm{ns}}$ \\
\hline $\begin{array}{l}\text { SRP (CDWS) (CDS)- SRP } \\
\text { (CDS) }\end{array}$ & -0.103 & 0.03 & 0.01 & -2.341 & $0.031^{\star *}$ \\
\hline Temp (CDWS)- Temp (HDS) & -4.15 & 0.96 & 0.27 & -15.57 & $0.000^{\star *}$ \\
\hline TDS (CDWS)- TDS (HDS) & -0.62 & 36.01 & 9.99 & -0.06 & 0.950 \\
\hline $\mathrm{EC}(\mathrm{CDWS})-\mathrm{EC}(\mathrm{HDS})$ & 1.9 & 0.04 & 0.03 & 0.934 & 0.049 \\
\hline $\begin{array}{l}\text { Turbidity (CDWS) vs } \\
\text { Turbidity (CDS) }\end{array}$ & 2.32 & 0.03 & 0.02 & 2.13 & 0.038 \\
\hline $\mathrm{pH}(\mathrm{CDWS})-\mathrm{pH}(\mathrm{HDS})$ & -1.02 & 0.38 & 0.11 & 9.72 & $0.000 * *$ \\
\hline DO (CDWS)- DO (HDS) & -1.55 & 0.29 & 0.08 & -19.38 & $0.000 * *$ \\
\hline $\begin{array}{l}\text { Chlo-a (CDWS) - Chloa } \\
\text { (HDS) }\end{array}$ & -4.90 & 3.10 & 0.86 & -5.71 & $0.000^{\star *}$ \\
\hline
\end{tabular}


Nitrite, sulfate, and phosphate occur naturally from the weathering process. The study showed a spatial and seasonal variation of nitrite and SRP concentration in the lake (Table 1). The mean value of nitrite was lower at the western part of the lake during both HDS and CDWS (Fig. 2). The concentration increased significantly $(\mathrm{p}<0.05)$ during the CDWS as compared to HDS (Table 2$)$. Researchers such as Van Loon \& Duffy (2005) suggested that excessive $\mathrm{NO}_{3}{ }^{-}$is highly linked to human health problems such as methemoglobinemia, gastric cancers, goiter, and hypertension. Nitrite was found to be higher than the recommended values for healthy freshwater ecosystems (Table 1). Studies have shown that nitrite becomes less toxic in the presence of calcium and chloride. However, the values of these major ions reported in this study are much lower $(18.74 \mathrm{meq} / \mathrm{L}, 20.13 \mathrm{meq} / \mathrm{L})$ than the recommended values $(76.56$ $\mathrm{meq} / \mathrm{L}$ and $<250 \mathrm{meq} / \mathrm{L}$ ) for a healthy freshwater aquatic ecosystem. The Environmental Protection Agency report also indicates that nitrite above $0.06 \mathrm{mg} / \mathrm{L}$ is generally toxic to fish (EPA, 1976) and can convert hemoglobin to methemoglobin causing pathological changes in fish organs and tissues under continuous exposure (Boyd, 1982). Steinman et al (2014) also noted that fish species such as catfish and tilapias are highly sensitive to nitrite concentration. This suggests that increased nitrite concentration $(0.83 \mathrm{mg} / \mathrm{L})$ during CDWS and $(0.27 \mathrm{mg} / \mathrm{L})$ during HDS reported in this study is worrisome to the aquatic biota. The turbidity was high during CDWS as compared to HDS. The increased turbidity during the CDWS was due to increased wind erosion, sand mining, and farming activities which are more prevalent in the study area. Researchers such as Razali et al. (2018) and Woldeab et al. (2019) explained that increased agricultural activities are highly linked to increased turbidity. Studies conducted by Mwafongo (1998), Jamu et al. (2011), and Palamuleni et al (2011) revealed that there has been a major land-use change in the west part of Lake Malombe catchment due to increased agricultural activities and these changes have been linked to increased gullying of the catchment, culminating in significant sedimentation of the lake littoral plain. 
Table 1

Mean and range of some of the physical-chemical variables and Chlo-a of Lake Malombe

\section{Season}

CDWS

HDS

\begin{tabular}{|c|c|c|c|c|c|c|}
\hline Parameter & Mean & Range & Mean & Range & MRL & Reference \\
\hline $\mathrm{WT}\left({ }^{0} \mathrm{C}\right)$ & $\begin{array}{l}26.15 \pm \\
0.15\end{array}$ & $\begin{array}{l}26.15- \\
24.3\end{array}$ & $\begin{array}{l}27.25 \pm \\
0.12\end{array}$ & $\begin{array}{l}27.13- \\
27.37\end{array}$ & 30 & WHO (2011) \\
\hline $\mathrm{pH}$ & - & $7.72-8.02$ & & $\begin{array}{l}8.94- \\
9.19\end{array}$ & $\begin{array}{l}6.5 \\
-9.0\end{array}$ & EPA (1976) \\
\hline $\mathrm{DO}(\mathrm{mg} / \mathrm{L})$ & $\begin{array}{l}6.05 \pm \\
0.12\end{array}$ & $6.14-6.29$ & $\begin{array}{l}7.90 \\
\pm .021\end{array}$ & $\begin{array}{l}7.89- \\
7.92\end{array}$ & $>7$ & $\begin{array}{l}\text { United Nations, } \\
(1992)\end{array}$ \\
\hline DO (\%) & $\begin{array}{l}78.61 \pm \\
1.43\end{array}$ & $\begin{array}{l}79.78- \\
81.72\end{array}$ & $\begin{array}{l}102.64 \pm \\
0.13\end{array}$ & $\begin{array}{l}102.51- \\
102.9\end{array}$ & $\begin{array}{l}90- \\
110\end{array}$ & $\begin{array}{l}\text { United Nations, } \\
\text { (1992) }\end{array}$ \\
\hline $\begin{array}{l}\text { Turbidity } \\
\text { (NTU) }\end{array}$ & $\begin{array}{l}7.92 \pm \\
0.01\end{array}$ & $7.83-4.56$ & $\begin{array}{l}5.58 \pm \\
0.01\end{array}$ & $\begin{array}{l}3.45- \\
6.45\end{array}$ & $<5$ & WHO (2011) \\
\hline $\mathrm{EC}(\mu \mathrm{S} / \mathrm{cm})$ & 165.3 & $\begin{array}{l}104.42- \\
184.33\end{array}$ & 163.4 & $\begin{array}{l}107.42- \\
144.32\end{array}$ & 1000 & EPA (1976) \\
\hline $\mathrm{Ca}^{2+}(\mathrm{meq} / \mathrm{L})$ & $\begin{array}{l}18.74 \pm \\
0.315\end{array}$ & $\begin{array}{l}18.43- \\
19.06\end{array}$ & $\begin{array}{l}17.36 \pm \\
0.42\end{array}$ & $\begin{array}{l}16.93- \\
17.79\end{array}$ & 76.56 & $\begin{array}{l}\text { Berner \& Berner, } \\
\text { (1987) }\end{array}$ \\
\hline $\mathrm{Mg}^{2+}(\mathrm{meq} / \mathrm{L})$ & $\begin{array}{l}9.88 \pm \\
0.72\end{array}$ & $\begin{array}{l}9.63- \\
10.14\end{array}$ & $\begin{array}{l}9.94 \pm \\
0.42\end{array}$ & $\begin{array}{l}10.55- \\
10.77\end{array}$ & 34.8 & $\begin{array}{l}\text { Berner \& Berner, } \\
\text { (1987) }\end{array}$ \\
\hline $\mathrm{Na}^{+}(\mathrm{meq} / \mathrm{L})$ & $\begin{array}{l}19.78 \pm \\
0.43\end{array}$ & $\begin{array}{l}4.74- \\
10.76\end{array}$ & $\begin{array}{l}23.67 \pm \\
1.19\end{array}$ & $\begin{array}{l}22.48- \\
24.86\end{array}$ & 53.36 & $\begin{array}{l}\text { Berner \& Berner, } \\
\text { (1987) }\end{array}$ \\
\hline $\mathrm{K}^{+}(\mathrm{meq} / \mathrm{L})$ & $\begin{array}{l}6.28 \pm \\
0.16\end{array}$ & $6.12-6.44$ & $\begin{array}{l}7.89 \pm \\
0.45\end{array}$ & $\begin{array}{l}7.57- \\
8.21\end{array}$ & 6.96 & $\begin{array}{l}\text { Berner \& Berner, } \\
\text { (1987) }\end{array}$ \\
\hline $\mathrm{Cl}^{-}(\mathrm{meq} / \mathrm{L})$ & $\begin{array}{l}20.13 \pm \\
0.21\end{array}$ & $\begin{array}{l}17.15- \\
23.11\end{array}$ & $\begin{array}{l}42.28 \pm \\
0.21\end{array}$ & $\begin{array}{l}42.07- \\
42.49\end{array}$ & $<250$ & EPA (1976) \\
\hline $\mathrm{CO}_{3}{ }^{2-}(\mathrm{meq} / \mathrm{L})$ & $\begin{array}{l}11.43 \pm \\
0.61\end{array}$ & $\begin{array}{l}8.82- \\
14.04\end{array}$ & $\begin{array}{l}19.74 \pm \\
1.32\end{array}$ & $\begin{array}{l}18.42- \\
21.06\end{array}$ & $0-75$ & EPA (1976) \\
\hline $\begin{array}{l}\mathrm{HCO}^{3-} \\
\text { (meq/L) }\end{array}$ & $\begin{array}{l}149.60 \pm \\
0.34\end{array}$ & $\begin{array}{l}148.66- \\
150.55\end{array}$ & $\begin{array}{l}118.76 \pm \\
0.45\end{array}$ & $\begin{array}{l}114.31- \\
123.22\end{array}$ & NA & \\
\hline $\begin{array}{l}\text { Sulphate } \\
\text { (mg/L) }\end{array}$ & $\begin{array}{l}1.01 \pm \\
0.58\end{array}$ & $0.60-1.43$ & $\begin{array}{l}1.51 \pm \\
0.91\end{array}$ & $\begin{array}{l}0.60- \\
2.43\end{array}$ & 150 & WHO (2004) \\
\hline Nitrite (mg/L) & $\begin{array}{l}0.83 \pm \\
0.14\end{array}$ & $0.73-0.93$ & $\begin{array}{l}0.27 \pm \\
0.00\end{array}$ & $\begin{array}{l}0.27- \\
0.32\end{array}$ & 0.06 & EPA (1976) \\
\hline $\mathrm{SRP}(\mathrm{mg} / \mathrm{L})$ & $\begin{array}{l}0.010 \pm \\
0.001\end{array}$ & $\begin{array}{l}0.016- \\
0.004\end{array}$ & $\begin{array}{l}0.15 \pm \\
0.00\end{array}$ & $\begin{array}{l}0.24- \\
0.09\end{array}$ & 0.025 & EPA (1976) \\
\hline
\end{tabular}




\begin{tabular}{|lllllll|}
\hline Season & CDWS & \multicolumn{7}{c|}{ HDS } \\
\hline TDS mg/L & $134.50 \pm$ & $134.00-$ & $169.50 \pm$ & $105.00-$ & 50 to & EPA (1976) \\
& 0.50 & 135.00 & 0.56 & 234.00 & 250 & \\
\hline Chlo a $(\mu \mathrm{g} / \mathrm{L})$ & $3.51 \pm$ & $3.11-3.92$ & $12.25 \pm$ & $11.13-$ & $<4$ & United Nations, \\
& 0.40 & & 0.11 & 13.36 & & (1992) \\
\hline \multicolumn{7}{l}{$\begin{array}{l}\text { SRP means soluble reactive phosphate, CDWS means cool dry windy season, HDS means hot dry } \\
\text { season, WT means water temperature }\end{array}$} \\
\hline
\end{tabular}

The presence of sulfate in a very high concentration is also associated with respiratory problems and in conjunction with sodium and magnesium, sulfate can exert a cathartic effect on digestive tracts. The paired t-test (Table 2 ) showed that the $\mathrm{SO}_{4}{ }^{2-}$ concentration was not significantly $(p<0.05)$ different. The middle section of the lake recorded the highest during the HDS while the inlet recorded the highest during the CDWS (Fig. 2). The $\mathrm{SO}_{4}{ }^{2-}$ value recorded in this study, however, was below the global freshwater values and $\mathrm{WHO}$ guidelines for freshwater $(\mathrm{WHO}, 2004)$. The low $\mathrm{SO}_{4}{ }^{2-}$ concentration in Lake Malombe was because African Great Lakes such as Lake Malawi are known for having low sulfate concentrations (Hecky \& Bugenyi, 1996) and most of the water in Lake Malombe comes from Lake Malawi through an $18 \mathrm{~km}$ stretch of Upper Shire River. Some studies have even suggested that the $\mathrm{SO}_{4}{ }^{2-}$ in African Great Lakes is low enough to limit phytoplankton growth for example in Lake Victoria, though more recent experiments indicate this is not the case (Ndebele-Murisa et al. 2010). The classical model of lake eutrophication explains that biogeochemical processing of phosphorous varies with season and this provides an indicator of increased anthropogenic activities, nutrient input from the surrounding watershed, and climatic forces which influence water residence time and the productivity of the lake by increasing algal growth, bacterial metabolism, and nutrient recycling rates during the HDS. The SRP was the highest at the outlet during CDWS and lowest during the HDS (Fig. 2). Inlet, on the other hand, recorded the highest SRP during the HDS as compared to CDWS. The concentration of SRP further exponentially increased (Fig. 3a) with an increase in water depth. The bottom of the lake also displayed a higher value of SRP which was attributed to P release from the bottom sediments (Golterman, 2004; Stephen et al. 1997). Researchers such as Boström et al. (1988), and Kowalczewska-Madura et al. (2018) suggested that phosphorus from the bottom sediments in shallow lakes such as Lake Malombe can contribute up to $99 \%$ of the total P pool. Ndebele-Murisa et al. (2010) on the other hand suggested that primary production is significantly influenced by nutrient concentration and these in return are affected by thermal stratification which is common in many tropical African lakes such as Lake Malombe. Table 1 further showed higher oxygen saturation during the HDS than during the CDWS. The higher DO saturation during the HDS was due to increased photosynthetic activities. The SRP level reported in this study was further higher than those reported in Lake Malawi suggesting that Lake Malombe is a nutrient-rich lake as compared to Lake Malawi which is attributed to its shallowness and inflowing nutrient-rich water from its highly populated catchment. 
The Chlo-a was high during the HDS as compared to CDWS. The western section of the Lake recorded the highest Chlo-a during the HDS and the outlet recorded the highest during the CDWS (Fig. 2). The charge balance of both cations and anions for all water samples calculated from the individual cation and anion concentrations (Table 1) was low (less than $10 \%$ on a morality basis) which conforms to the findings of Reid et al. (1999). The order of major cations and anions is $\mathrm{Ca}^{2+}<\mathrm{Na}^{+}<\mathrm{Mg}^{2+}<\mathrm{K}^{+}<\mathrm{HCO}^{3-}<\mathrm{Cl}^{-}<\mathrm{CO}_{3}{ }^{2-}<$ $\mathrm{SO}_{4}{ }^{2-}$ respectively. The paired t-test in Table 2 shows that the concentration of major ions such as $\mathrm{Na}^{+}$, $\mathrm{K}^{+}, \mathrm{Cl}^{-}$, and $\mathrm{CO}_{3}{ }^{2-}$ significantly $(\mathrm{p}<0.05)$ varied with season. The concentration of these ions except $\mathrm{CO}_{3}{ }^{2-}$ was higher during the HDS than CDWS. Although the geochemistry of Lake Malombe is determined by the water it receives from Lake Malawi, the concentration of major ions (except $\mathrm{Ca}^{2+}$ and $\mathrm{Mg}^{2+}$ ) during both HDS and CDWS were higher than those reported in Lake Malawi. The increased concentration of these ions in Lake Malombe was attributed to increased sediment loss from the lake catchment due to increased anthropogenic activities as well as weathering processes instigated by increased temperatures and wind speed. According to Abubeker, (2017), sediment loss around Lake Malombe catchment is estimated at 10 tons per hectare annually. On the other hand, a significant decrease in calcium and magnesium concentration (below values reported in Lake Malawi by Hecky et al. 2006) was attributed to the increased snail population (Kamtambe et al. 2019), high evaporation rate instigated by rising atmospheric temperatures (El Gammal et al. 2017 ) and longer hydraulic residence time which allows the possible accumulation of ions in the sediments, (Saleem et al. 2015; Reid et al. 1999; Bootsma \& Hecky, 2003, Jeong et al. 2007). Table 2 further showed that the concentration of the major elements recorded in Lake Malombe was below the global freshwater values (Berner \& Berner, 1987) suggesting that Lake Malombe to some extent displays the similar geochemical characteristics of major African Great Rift Valley lakes (Bootsma \& Hecky, 2003).

\section{Spatial variation of Zooplankton density and its interaction with physical-chemical variables and Chlo a}

Zooplankton species undergo physiological changes as a strategy for surviving in different aquatic systems (Richardson, 2008). With the current study site being an inland closed-basin lake with some sampling sites located further away from the discharge point of the main Shire River (inshore areas), some differences in zooplankton density were predicted. The zooplankton density exhibited strong spatial and seasonal variations (Fig. 4). Similar to other lakes in temperate and tropical regions, zooplankton density was dominated by copepods (Tropodiaptomus cunningtoni, Nauplii, Mesocyclops aequatorialis aequatorialis), Cyclopidae (Thermocyclops neglectus), Cladocera (Bosmina longirostris), Ctenopod (Diaphanosoma excisum), and Rotifers. Tropodiaptomus cunningtoni is also found in Lake Malawi (Ngochera \& Bootsma, 2011) and its presence in Lake Malombe is linked to the fact that these two lakes share some unique characteristics of the larger lake's aquatic ecology. The Eastern part of the lake had the highest population of dominant zooplankton species (T. cunningtoni, M. aEq. Aequatorialis, T. neglectus, Bosmina longirostris, Diaphanosoma spp, Nauplii, and Rotifers) during the winter (Fig. 4). High dominant zooplankton communities in the eastern part of the lake were attributed to the fact that this area is relatively shallow with high-water temperatures, $\mathrm{pH}$, and lowest nitrite which create a conducive environment for the growth and distribution of zooplankton species. The increase in 
zooplankton species in the eastern part of the lake is further evidenced by a decrease in chlo-a suggesting that phytoplankton species are highly grazed by the large population of zooplankton species. The HDS also recorded high zooplankton species in the eastern part of the lake (T. cunningtoni, $M$. aEq. Aequatorialis, T. neglectus, Bosmina longirostris, Diaphanosoma spp, Nauplii) though Rotifer reported to be high at the lake outlet. The high population of Rotifer at the lake outlet during HDS was attributed to the increase in water current as well as high dissolved oxygen. The increase in zooplankton density during the HDS can further be explained by increased phytoplankton biomass from HDS to CDWS and this especially occurs in eutrophic lakes such as Lake Malombe where climate change might lengthen cyanobacterial growth season (Schagerl \& Oduor, 2008; Paerl \& Paul, 2012). This explains that the increased rate of grazing during the HDS as compared to the CDWS could be associated with an increased zooplankton population in the lake. For example, Nauplii require a much higher food concentration for development than copepods. Their low ingestion rates indicate that low feeding efficiency can be the reason for their high food demand (Sinistro, 2010). Under conditions of food scarcity (for example during the CDWS where Chlo a is significantly lower as seen in Table 2), some Nauplii spp have a lower survival rate. This explains the reason for their low abundance during the CDWS. A similar observation is made in Rotifer. The positive correlation coefficient (Table 3) explains that phytoplankton abundance in the lake stimulated the increased zooplankton population. Many researchers have also suggested that phytoplankton is the primary producer in the complex food web system and this phytoplankton also produce oxygen and organic matter through photosynthesis. This mechanism provides a better connection between primary producers with more advanced consumers in the biological chain and provides a crucial link in the aquatic food web system ( $\mathrm{Li}$ et al. 2020). The changes in zooplankton density as seasonal changes are predominately influenced by physical-chemical (bottom-up effects) and predation (top-down effects) through the aquatic food web (Lv et al 2011; Muhid et al. 2013; Li et al., 2020). 
Table 3

Karl Pearson's correlation between physical-chemical variables, Chlo-a and the dominant zooplankton density

\begin{tabular}{|c|c|c|c|c|c|c|c|}
\hline Parameters & TC & MAA & $\mathrm{TN}$ & $\mathrm{BL}$ & DS & Nauplii & Rotifers \\
\hline WT $\left({ }^{\circ} \mathrm{C}\right)$ & $0.568^{*}$ & $0.577^{\star}$ & $0.401^{\star}$ & 0.264 & $0.619 \star \star$ & $.484^{\star}$ & $0.655^{\star \star}$ \\
\hline $\mathrm{pH}$ & $0.661^{\star \star}$ & $0.582^{*}$ & $0.461^{\star}$ & 0.208 & $0.607 \star \star$ & $0.425^{\star}$ & $0.539 * *$ \\
\hline DO & $0.729 * *$ & $0.513^{\star \star}$ & $0.501^{\star *}$ & 0.290 & $0.666^{\star *}$ & $0.510 * *$ & $0.632^{\star *}$ \\
\hline $\mathrm{Ca}^{2+}$ & 0.065 & 0.092 & -0.016 & 0.101 & 0.099 & 0.148 & 0.088 \\
\hline $\mathrm{Mg}^{2+}$ & 0.250 & 0.220 & 0.176 & 0.274 & 0.296 & 0.310 & 0.218 \\
\hline $\mathrm{Na}^{+}$ & $0.546^{\star}$ & $0.427 *$ & 0.354 & 0.333 & $0.574^{\star \star}$ & 0.504 ** & $0.515^{\star \star}$ \\
\hline $\mathrm{K}^{+}$ & $0.562^{\star}$ & $0.425^{\star}$ & 0.390 & 0.325 & $0.577^{\star \star}$ & $.492^{\star}$ & $0.517^{\star \star}$ \\
\hline $\mathrm{Cl}^{-}$ & 0.316 & 0.326 & 0.367 & 0.207 & $0.488^{*}$ & 0.399 & $0.472^{\star}$ \\
\hline $\mathrm{CO}_{3}{ }^{2-}$ & $0.507 * \star$ & 0.352 & 0.300 & 0.310 & 0.011 & 0.044 & 0.015 \\
\hline $\mathrm{HCO}^{3-}$ & -0.074 & 0.186 & 0.077 & 0.235 & $.619 \star \star$ & 0.334 & $0.580 \star \star$ \\
\hline $\mathrm{SO}_{4}{ }^{2-}$ & -0.032 & 0.093 & 0.241 & 0.303 & 0.146 & 0.323 & 0.058 \\
\hline Nitrite & $-0.562^{\star}$ & $-0.521^{\star}$ & $-0.523^{\star}$ & $0.541^{\star}$ & $-0.651 * \star$ & $0.503^{*}$ & $0.513^{\star}$ \\
\hline TDS & 0.017 & -0.099 & 0.297 & $-0.523^{\star}$ & -0.224 & $-.535^{\star \star}$ & $-0.506 * \star$ \\
\hline SRP & $0.523^{\star}$ & $0.563^{*}$ & $0.501^{\star}$ & 0.542 & 0.571 & 0.563 & 0.546 \\
\hline Chlo a & $0.526^{\star}$ & $0625^{\star \star}$ & $0.631^{\star \star}$ & $0.508^{*}$ & $0.618^{\star \star}$ & $0.585^{\star}$ & $0.576^{\star}$ \\
\hline
\end{tabular}

Figure 5 shows the canonical correspondence analysis (CCA) of zooplankton density and water physicalchemical variables as well as Chlo-a. Pomati et al (2020) noted that the total abundance of phytoplankton is strongly linked to total nutrient loading (phosphorous and nitrogen) available in the system. In this study, the arrow length indicates the significance of the variable and shows positive or negative correlations with the axis. The percentage of variance and Eigenvalues of each site on axis 1 was higher than axis 2. At Lake Malombe West, CCA was drawn between 14 physical-chemical variables and Chlo-a and the dominant zooplankton density. The eigenvalue for axis 1 (0.009) explained 98.3\% correlation and axis $2(0.002)$ explained $22.36 \%$ correlation between physical-chemical variables, Chlo-a, and dominant zooplankton. The $\mathrm{pH}$ and $\mathrm{DO}$ showed a close relationship with the zooplankton community, which shows high productivity in the western part of the lake. Nauplii, R, and BL were 
positively correlated with axis 1 and also indicated a positive correlation with $\mathrm{Mg}^{2+}, \mathrm{pH}, \mathrm{SO}_{4}{ }^{2-}, \mathrm{HCO}^{3-}$, Nitrite, SRP, $\mathrm{Ca}^{2+}$, and Chlo-a. However, DS, TC, TN, MAA were positively correlated with axis 2 and further shows a positive correlation with $\mathrm{CO}_{3}{ }^{2-}$ WT, TDS, DO, $\mathrm{Cl}^{-}$and $\mathrm{Na}^{+}$. The population density of DS, TC, TN, MAA were negatively affected by $\mathrm{Mg}^{2+}, \mathrm{pH}, \mathrm{SO}_{4}{ }^{2-}, \mathrm{HCO}^{3-}$, Nitrite, $\mathrm{Ca}^{2+}$. Naupilli, $\mathrm{R}$ and $\mathrm{BL}$ were negatively affected by $\mathrm{CO}_{3}{ }^{2-}, \mathrm{WT}, \mathrm{TDS}, \mathrm{Cl}^{-}$. At Lake Malombe outlet, 14 physical-chemical variables and Chlo-a and the dominant zooplankton density were taken into consideration to draw CCA. Lake Malombe outlet had the most abundant zooplankton species. On-axis 1, Eigenvalue (0.022) explained $80.37 \%$ and Eigenvalue of axis $2(0.005)$ explained $19.63 \%$ correlation between physical-chemical variables and Chlo-a and dominant zooplankton density. The R, TN, TC, DS showed a positive correlation with xis 1 which indicates the effect of $\mathrm{Cl}^{-}, \mathrm{CO}_{3}{ }^{2-}, \mathrm{HCO}^{3-}, \mathrm{SO}_{4}{ }^{2-}, \mathrm{DO}, \mathrm{SRP}$ and Nitrite. Naupilli, MAA, BL showed a positive relationship with Axis 2 and positively affected by WT, $\mathrm{pH}, \mathrm{Ca}^{2+}, \mathrm{Mg}^{2+}, \mathrm{Na}^{+}, \mathrm{K}^{+}$, and $\mathrm{CO}_{3}{ }^{2-}$. At Lake Malombe middle, the Eigenvalue at axis 1 was $(0.0169)$ and explained $93.31 \%$ of the correlation while Eigenvalue at axis 2 was (0.001) explained 6.69\% correlation between physical-chemical variables and Chlo-a and dominant zooplankton density. Lake Malombe inlet, on the other hand, had an Eigenvalue of axis 2 (0.001) and explained $76.4 \%$ of the correlation. The R, MAA, and DS correlated positively with axis 1 and $\mathrm{HCO}^{3-}, \mathrm{DO}, \mathrm{SO}_{4}{ }^{2-}, \mathrm{Cl}^{-}$, Chlo a, and $\mathrm{CO}_{3}{ }^{2-}$ were positive while Nauplii, $\mathrm{BL} \mathrm{TC}$, and TN were correlated positively with axis 2 and with $\mathrm{pH}$, nitrite, and TDS. Figure 5 further shows that these had Eigenvalue (0.009) and explained $88.1 \%$ of correlation at axis 1 . On the other hand, axis 2 had Eigenvalue (0.0013) and explained 11.9 of correlation. TN, DS, R positively correlated with axis 1 while BL, Nauplii, TC, MAA positively correlated with axis 2 . The $\mathrm{Ca}^{2+}, \mathrm{Chlo} \mathrm{a}, \mathrm{CO}_{3}{ }^{2-}, \mathrm{Mg}^{2+}, \mathrm{Na}^{+}, \mathrm{Cl}^{-}$and $\mathrm{DO}$ positively correlated with DS, R, TN while BL, Nauplii, TC, MAA correlated positively with Nitrite, SRP, $\mathrm{SO}_{4}{ }^{2-}, \mathrm{pH}$, and $\mathrm{HCO}^{3-}$. $\mathrm{Na}^{+}$ also showed a positive relationship with TC, MAA, DS, Nauplii, and Rotifers.

Pearson correlation analysis results in Table 3 confirmed that zooplankton species density in the lake followed distinct sequences regulated by the water physical-chemical variables such as WT, pH, DO, nutrients (Kimmel \& Groeger, 1984). Karl Pearson's correlation between WT, SRP, nitrite, pH, DO, chlo-a, and zooplankton density in Table 3 were positive. El Gammal et al. (2017) acknowledged that the pH range within (8-9) is appropriate for the development of zooplankton. The $\mathrm{Cl}^{-}$also displayed a positive relationship with Diaphanosoma excisum and Rotifers and had a correlation coefficient of $(r=0.488 ; r=$ 0.472). The $\mathrm{CO}_{3}{ }^{2-}$ and TDS showed a negative relationship with Bosmina longirostris, Nauplii, Rotifers $(r=-0.423 ; r=-0.535 ; r=-0.506)$. The factors depicted in this study may not be the only factors influencing the zooplankton population variation in Lake Malombe during the CDWS and HDS. Predator abundance and the absence of predators also play an important role. For example, there is a piece of general evidence that crustaceans can effectively influence the Rotifer population via predation and competition. In the case of Lake Malombe, the dominant crustacean is Bosmina longirostris. Rotifer could be also the main food source for Cladocera, cyclopoid, copepods, calanoid, and predatory rotifers, though this kind of predator/prey relationship is ephemeral as rotifers evolve many defense mechanisms against invertebrate predators. The upper trophic levels could also influence nutrients availability for primary 
consumers via the stoichiometry of nutrient recycling. Studies have shown that C: $\mathrm{N}$ and C:P ratios vary among the zooplankton species (Van Nieuwerburgh et al. 2004; Rhee \& Gotham, 2008; Burkhardt et al. 1999). For example, Cladocera has a higher proportion of phosphorous and a lower proportion of nitrogen than copepods (Sommer \& Sommer, 2006; Walve \& Larsson, 1999). This differential nutrient uptake modifies the proportion of nutrients in the water column during both HDS and CDWS. Karl Pearson's correlation in Table 3 demonstrates a positive significant correlation coefficient between WT and Diaphanosoma spp, Thermocyclops neglectus, Rotifers, and Tropodiaptomus cunningtoni suggesting that rising WT reported during the HDS is associated with the increase in the population of these species. Similar findings have been reported in other African tropical lakes such as Lake Chad and Lake George, Lake Kariba (Talling, 1986; Moyo, 1991). As observed in other studies, the low temperature can lead to a decrease in zooplankton density in the lake (Brucet et al., 2010; Cremona et al. 2020; Pomati et al. 2020; Li et al. 2020). In early HDS, Chlo-a develops when nutrients are available and when temperatures are high. Under warmer water temperatures, Chlo-a becomes dominant. Some zooplankton groups become sensitive to water mixing; therefore, their dominance in HDS can be explained by the thermal stratification phenomena which prevent water mixing.

\section{Conclusion}

In this study, the biomass for phytoplankton and zooplankton density was very high during the HDS as compared to CDWS. The highest biomass of phytoplankton recorded during the HDS was mainly attributed to the relatively high WT, pH, and SRP concentration. The study identified that copepods (Tropodiaptomus cunningtoni, Nauplii, Mesocyclops aequatorialis aequatorialis), Cyclopidae (Thermocyclops neglectus), Cladocera (Bosmina longirostris), Ctenopod (Diaphanosoma excisum), and Rotifers as dominant zooplankton. Tropodiaptomus cunningtoni are more dominant in HDS when nutrients are available and WT is high. Interestingly, the results further revealed that $W T, p H, D O$, nutrient loading, and some major ions as well as Chlo-a were the most important variables influencing the zooplankton density in the lake. The findings of this study serve as a basis for understanding how unpredictable spatial and seasonal variability of physical-chemical variables and Chlo-a influence zooplankton density, which have implications for developing sustainable management strategies and conservation of inland tropical shallow lakes.

\section{Declarations}

Author Contributions: RM. conceptualized the study, developed the methodology, sourced the data, analyzed the data, and developed the original manuscript. Authors SM, EK, TA supervised the study, reviewed and edited the manuscript, visualized, and validated the study. All authors have read and agreed to the published version of the manuscript.

Acknowledgment: The authors wish to thank the Department of Fisheries particularly the Senga Bay Fisheries Research Center for the water sample laboratory analysis. All the Senga Bay Research station technical staff are further appreciated for their hardworking and effort during the data collection. 
Funding: This research was funded by the Federal Democratic Republic of Ethiopia through the African Centre of Excellence for Water Management, Addis Ababa University, Grant number GSR/9316/11. The data collection exercise was funded by "Increasing resilience to climate change in the Fisheries Sector of South Lake Malawi and Lake Malombe" implemented by FAO in collaboration with Fisheries Department of the Ministry of Natural Resources and Forestry, Malawi Government funded by Global Environmental Facility: project number TCP/MLW/3504.

Ethics Approval: Not applicable

Consent to Participate: Not applicable

Consent for publication: Not applicable

Data Availability Statement: The datasets used and/or analysed during the current study are available from the corresponding author on reasonable request

Conflicts of Interest: The authors of this paper declare that there is no conflict of interest.

\section{References}

1. Abubeker A (2017) Lake Malawi Catchment: main characteristics and way forward. Land Resources Consultancy. Presentation. Mangochi District Council, Mangochi

2. Afonina E, Tashlykova N (2018) Plankton community and the relationship with the environment in saline lakes of Onon-Torey plain, Northeastern Mongolia. Saudi Journal of Biological Sciences, 25(2018)399-408

3. Anseeuw D, Raeymaekers J, Busselen P, Verhey E, Snoek J (2011) Low Genetic and Morphometric Intraspecific Divergence in Peripheral Copadichromis Populations (Perciformes: Cichlidae) in the Lake Malawi Basin. International Journal of Evolutionary Biology, 2011, 11. doi:10.4061/2011/835946

4. APHA (1998) Standard Methods for the Examination of Water and Waste. American Public Health Association, Washington, DC

5. Berner E, Berner R (1987) Global water cycle geochemistry and environment. Prentice-Hall, Englewood Cliffs

6. Blum A, Lasaga A (1991) The role of surface speciation in the dissolution of albite. Geochim Cosmochim Acta 55(8):2193-2201,. https://doi.org/10.1016/0016-7037(91)90096-N

7. Bootsma H, Hecky R (2003) A Comparative Introduction to the Biology and Limnologyof the African Great Lakes. J Great Lakes Res 29(Supplement 2):3-18

8. Borics G, Abonyi A, Salmaso N, Ptacnik R (2021) Freshwater phytoplankton diversity: models, drivers, and implications for ecosystem properties. Hydrobiologia, 848(2021)53-75 
9. Boström B, Andersen J, Fleisher S, Jansson M (1988) Exchange of phosphorus across the sedimentwater interface. Hydrobiologia, 170(1988)229-244

10. Boyce D, Lewis M, Worm B (2010) Global phytoplankton decline over the past century. Nature, 466(2010)591-596

11. Boyd C (1982) Water quality management for pond fish culture. Elsevier Press, Amsterdam.

12. Brucet $S$, Boix D, Quintana X, Jensen E, Nathansen L, Trochine $C, \ldots$. Jeppesen $E$ (2010) Factors influencing zooplankton size structure at contrasting temperatures in coastal shallow lakes: Implication for effects of climate change. Limnol Oceanogr 55(4):1697-1711

13. Burkhardt S, Zondervan I, Riebesell U (1999) Effect of CO2 concentration on C: N:P in marine phytoplankton: A species comparison. Limnol Oceanogr 44(3):683-690

14. Coulter G, Allanson B, Bruton M, Greenwood P, Hart R, Jackson P, Ribbink A (1986) Unique qualities and special problems of the African Great Lakes. Environmental Biology of Fishes, 17(1986)161183

15. Cremona F, Agasild H, Haberman J, Zingel P, Nõges T, Laas A (2020) How warming and other stressors affect zooplankton abundance, biomass, and community composition in shallow eutrophic lakes. Climate change, 159(2020)565-580

16. Dulanya Z, Croudace I, Reed J, Trauth M (2014) Palaeolimnological reconstruction of recent environmental change in Lake Malombe (S.Malawi) using multiple proxies. Water SA 40(4):717726. http://dx.doi.org/10.4314/wsa.v40i4.17

17. El Gammal M, Nageeb M, Al-Sabeb S (2017) Phytoplankton abundance in relation to the quality of the coastal water - Arabian Gulf, Saudi Arabia. Egypt J Aquat Res 43(4):275-282

18. EPA (1976) Quality Criteria for Water. U.S Environmental Protection Agency, Washington DC

19. Fernando C (2002) A Guide to Tropical Freshwater Zooplankton Identification, Ecology and Impact on Fisheries. Backhuys Publishers, Leiden

20. Gebrehiwot M, Kifle D, Stiers I, Triest L (2017) Phytoplankton functional dynamics in a shallow polymictic tropical lake: the influence of emergent macrophytes. Hydrobiologia, 797(2017) 69-86

21. Golterman H (2004) The chemistry of phosphorous and nitrogen compounds in sediments. Kluwer Academic Publisher

22. Ha K, Kim H, Joo G (1998) The phytoplankton succession in the lower part of hypertrophic Nakdong River (Mulgum), South Korea. Hydrobiogia 369/370:217-227

23. Hamid A, Bhat S, Jehangir A (2020) LOcal determinants influencing stream water quality. Applied Water Science, 10, 24 (2020). https://doi.org/10.1007/s13201-019-1043-4

24. Hara M (2006) Restoring the chambo in southern Malawi: Learning from the past or re-inventing the wheel? Aquatic Ecosystem Health \&Management 9(4):419-432,.

https://doi.org/10.1080/14634980601013335

25. Hara M, Njaya F (2016) Between a rock and a hard place: The need for and challenges to implementation of rights-based fisheries management in small-scale fisheries of southern Lake 
Malawi. Fish. Res, 174 (2016)10-18

26. Hecky R, Bugenyi F (1996) Hydrology and chemistry of the African Great Lakes and water quality issues: Problems and solution. SIL Communications 23(1):45-54.

DOI:10.1080/05384680.1992.11904007

27. Hecky R, Bootsma H, Odada E (2006) African lake management initiatives: The global connection. Lakes and Reservoirs. Res. Manage., 11(2006)203-213

28. Holm-Hansen O, Lorenzen C, Holmes R, Strickland J (1965) Fluorometricdetermination of chlorophyll. Conseil International pour l’Exploration de la Mer,. Journaldu Conseil,, 301(1965)3-15

29. Jambo C, Hecht T (2001).. Effects of overfishing on the reproductive potential of major cichlid fish species in southern Lake Malombe (Malawi): need for "closed area" strategy as a complementary management option? Lake Malawi Fisheries Management Symposium Proceedings ((pp. 105-114). Lilongwe: Department of Fisheries

30. Jamu D, Banda M, Njaya F, Hecky R (2011) Challenges to the sustainable management of the lakes of Malawi. Great Lakes Research 37(1):3-14

31. Jeffrey S, Humphrey G (1975) New spectrophotometric equations for determining chlorophylls a, b, c1, and c2 in higher plants, algae, and natural phytoplankton. Biochemie und Physiologie der Pflanzen, 167(1975) 191-194

32. Jeong K, Kim D, Joo G (2007) Delayed influence of dam storage and discharge on the determination of seasonal proliferation of Microcystis aeruginosa and Stephanodiscus hantzschii in a regulated river system of lower Nakdong River (South Korea). Water Res, 41(2007)1269-1279

33. Kalumbi L, Thaulo C, MacPherson E, Tracy M (2020) Hygiene from a Fishing Community along Lake Malombe, Southern Malawi. Int J Environ Res Public Health 17(18):6703.

https://doi.org/10.3390/ijerph17186703

34. Kamtambe K, Banda J, Kaphuka B, Msiska O (2019) The abundance, distribution, and diversity of benthic invertebrates of Lake Malombe. Int J Fish Aquacult 11(2):13-22

35. Kimmel B, Groeger A (1984) Factors controlling primary production in lakes and reservoirs: A perspective. Lake Reservoir Management 1(1):277-281

36. Kowalczewska-Madura K, Dondajewska R, Gołdyn R, Kozak A, Messyasz B (2018) Internal Phosphorus Loading from the Bottom Sediments of a Dimictic Lake During its Sustainable Restoration. Water Air Soil Pollut, (2018) 229: 280

37. Li Y, Meng J, Zhang C, Ji J, Kong Q, Wang R, Liu J (2020) Bottom-up and top-down effects on phytoplankton communities in two freshwater lakes. PLoSONE 15(4):e023135. https://doi.org/10.1371/journal.pone.0231357

38. Liu C, Liu L, Shen H (2010) Seasonal variations of phytoplankton community structure in relation to Physico-chemical factors in Lake Baiyangdian, China. Procedia Environmental Sciences, 2(2010)1622-1631

39. Lv J, Wu H, Chen M (2011) Effect of nitrogen and phosphorous on phytoplankton composition in 15 subtropical, urban shallow lakes in Wuhan, China. Limnologica, 41(2011) 48-56 
40. Ma C, Mwagona P, Yu H, Sun X, Liang L, Al-Ghanim K, Mahboob S (2019) Spatial and temporal variation of phytoplankton functional groups in extremely alkaline Dali Nur Lake, North China. J Freshw Ecol 34(1):91-105

41. Magalhães D, Marques M, Baptista D, Buss D (2015) Metal bioavailability and toxicity in freshwater. Environmental Chemistry Letters, 13(2015) 69-87,https://doi.org/10.1007/s10311-015-0491-9

42. Makwinja R, Mengistou S, Kaunda E, Alemiew T, Phiri T, Kosamu I, Kaonga C (2021) Modeling of Lake Malombe Annual Fish Landings and Catch per Unit Effort (CPUE). Forecasting 3(1):39-55. https://doi.org/10.3390/forecast301000

43. Malawi Government (2013) Shire River basin Management Programme (Phase I) Project: Final Environmental and Social Assessment Report. Ministry of Water Development and Irrigation, Lilongwe

44. Moyo S (1991) Cyanobacterial nitrogen fixation in Lake Kariba, Zimbabwe. Verh Int Ver Limnol, 24(1991)1123-1127

45. Muhid P, Davis T, Bunn S, Burford M (2013) Effect of inorganic nutrients in recycled water on freshwater phytoplankton biomass and composition. Water Res 47(1):384-394

46. Murphy G, Romanuk T, Worm B (2020) Cascading effects of climate change on plankton community structure. Ecology and Evolution., 2020;10:2170-2181

47. Mwafongo W (1998) Land-use change and land degradation in West Malombe, Mangochi District, Malawi: a geographical study. Malawi J.Sci. Techno, 4(1998)13-35

48. Naumenko M (2008) Seasonality and trends in the Secchis disk transparency of Lake Ladoga.. Hydrobiologia, 599(2008)59-65

49. Ndebele-Murisa M, Musil C, Raitt L (2010) A review of phytoplankton dynamics in tropical African lakes. S Afr J Sci, 106 (1/2)1-6, DOI:10.4102/sajs.v106i1/2.64

50. Ngochera M, Bootsma H (2011) Temporal trends of phytoplankton and zooplankton stable isotope composition in tropical Lake Malawi. J Great Lakes Res 37(1):45-53,. https://doi.org/10.1016/j.jglr.2010.09.004

51. Paerl H, Paul V (2012) Climate Change: Links to the global expansion of harmful cyanobacteria. Water Res 46(5):1349-1363

52. Palamuleni L, Ndomba P, Annegarn H (2011) Evaluating land cover change and its impact on hydrological regime in Upper Shire river catchment, Malawi. Reg Environ Change 11(4):845-855

53. Pomati F, Shurin J, Andersen K, Tellenbach C, Barton A (2020) Interacting Temperature, Nutrients and Zooplankton Grazing Control Phytoplankton Size-Abundance Relationships in Eight Swiss Lakes. Front.Microbiol, https://doi.org/10.3389/fmicb.2019.03155

54. Razali A, Ismail S, Awang S, Praveena S, Abidin E (2018) Land-use change in the highland area and its impact on river water quality: a review of case studies in Malaysia. Ecological Processes, 7(19), https://doi.org/10.1186/s13717-018-0126-8 
55. Reid M, Kim J, Hunter K (1999) Trace metal and major ion concentrations in Lakes hayes and Manapouri. Journal of The Royal Society of New Zealand, 29(1999)244-255

56. Rhee G, Gotham I (2008) Optimum N:P ratios and coexistence in phytoplankton. J Phycol 16(4):486489

57. Richardson A (2008) In hot water: Zooplankton and climate change. ICES J Mar Sci 65(3):279-295,. https://doi.org/10.1093/icesjms/fsn028

58. Saleem M, Jeelani G, Shah R (2015) Hydrogeochemistry of Dal Lake and the potential for the present, future management by using facies, ionic ratios, and statistical analysis. Environmental Earth Science, 74(2015)3301-3313

59. Schagerl M, Oduor S (2008) Phytoplankton community relationship to environmental variables in three Kenyan Rift Valley saline-alkaline lakes. Marine and Freshwater Research, 59(2008)125-136

60. Shiel R (1995) A guide to the identification of rotifers, cladocerans, and copepods from Australian Inland Waters. Cooperative Research Centre for Freshwater Ecology Identification Guide no. 3. Murray Darling Freshwater Research Centre, Albury

61. Sinistro R (2010) Top-down and bottom-up regulation of planktonic communities in a warm temperate wetland. J Plankton Res 32(2):209-220

62. Sommer U, Sommer F (2006) Cladocerans versus copepods: the cause of contrasting top-down controls on freshwater and marine phytoplankton. Oecologia, 147(2006) 183-194. https://doi.org/10.1007/s00442-005-0320-

63. Steinman B, Brown E, Katsev S, Kelly S (2014) Future changes in Lake Malawi surface Elevation. Presentation. Mzuzu University. Large Lake Observatory, Water Resources Science, University of Minnesota, Duluth

64. Stephen D, Moss B, Phillips G (1997) Do rooted macrophytes increase sediment phosphorus release? In: Kufel L, Prejs A, Rybak J (eds) Shallow Lakes '95. Developments in Hydrobiology. Springer, Dordrecht, pp 27-34. doi:https://doi.org/10.1007/978-94-011-5648-6_3

65. Talling $\mathrm{J}$ (1986) The seasonality of phytoplankton in African lakes. Hydrobiologia, 138 (1986)139160 (1986). https://doi.org/10.1007/BF00027237

66. Teubner K (2003) Phytoplankton, pelagic community and nutrients in a deep oligotrophic alpine lake: ratios as sensitive indicators. Water Res, 37(2003)1583-1592

67. Tilahun G, Ahlgren G (2010) Seasonal variations in phytoplankton biomass and primary production in the Ethiopian Rift Valley lakes Ziway, Awassa, and Chamo-The basis for fish production. Limnologica, 40(2010)330-342

68. Tweddle D, Turner G, Seisay M (1995) Changes in species composition and abundance as a consequence of fishing in Lake Malombe, Malawi. In: Pitcher T, Hart P (eds) The Impact of Species Changes in African Lakes. Chapman \& Hall, London, pp 414-415

69. United Nations (1992) ECE Standard Statistical Classification of Surface Freshwater Quality for the Maintenance of Aquatic Life. United Nations, Geneva 
70. Van Loon G, Duffy S (2005) Environmental chemistry: a global perspective (2nd Edition ed.). Oxford: Oxford University Press

71. Van Nieuwerburgh L, Wänstrand I, Snoeijs P (2004) Growth and C: N:P ratios in copepods grazing on $\mathrm{N}$ - or Si-limited phytoplankton blooms. In: Kautsky H, Snoeijs P (eds) Biology of the Baltic Sea. Developments in Hydrobiology. Springer, Dordrecht

72. Vidal T, Calado A, Moita M, Cunha M (2017) Phytoplankton dynamics in relation to seasonal variability and upwelling and relaxation patterns at the mouth of Ria de Aveiro (West Iberian Margin) over four years. PLoS ONE 12(5):e0177237. https://doi.org/10.1371/journal.pone.0177237

73. Walve J, Larsson U (1999) Carbon, nitrogen and phosphorus stoichiometry of crustacean zooplankton crustacean zooplankton in the Baltic Sea: implications for nutrient recycling. J Plankton Res 21(12):2309-2321

74. WHO (2004) Sulfate in drinking-water. Background document for development of WHO guidelines for drinking-water quality. World Health Organisation, Geneva

75. WHO (2011) Guidelines for drinking-water quality, 4th ed.).. World Health Organization, Geneva

76. Woldeab B, Ambelu A, Mereta S, Beyene A (2019) Effect of watershed land use on tributaries' water quality in the East African Highland. Environ Monit Assess, 191(36), https://doi.org/10.1007/s10661018-7176-3

\section{Figures}




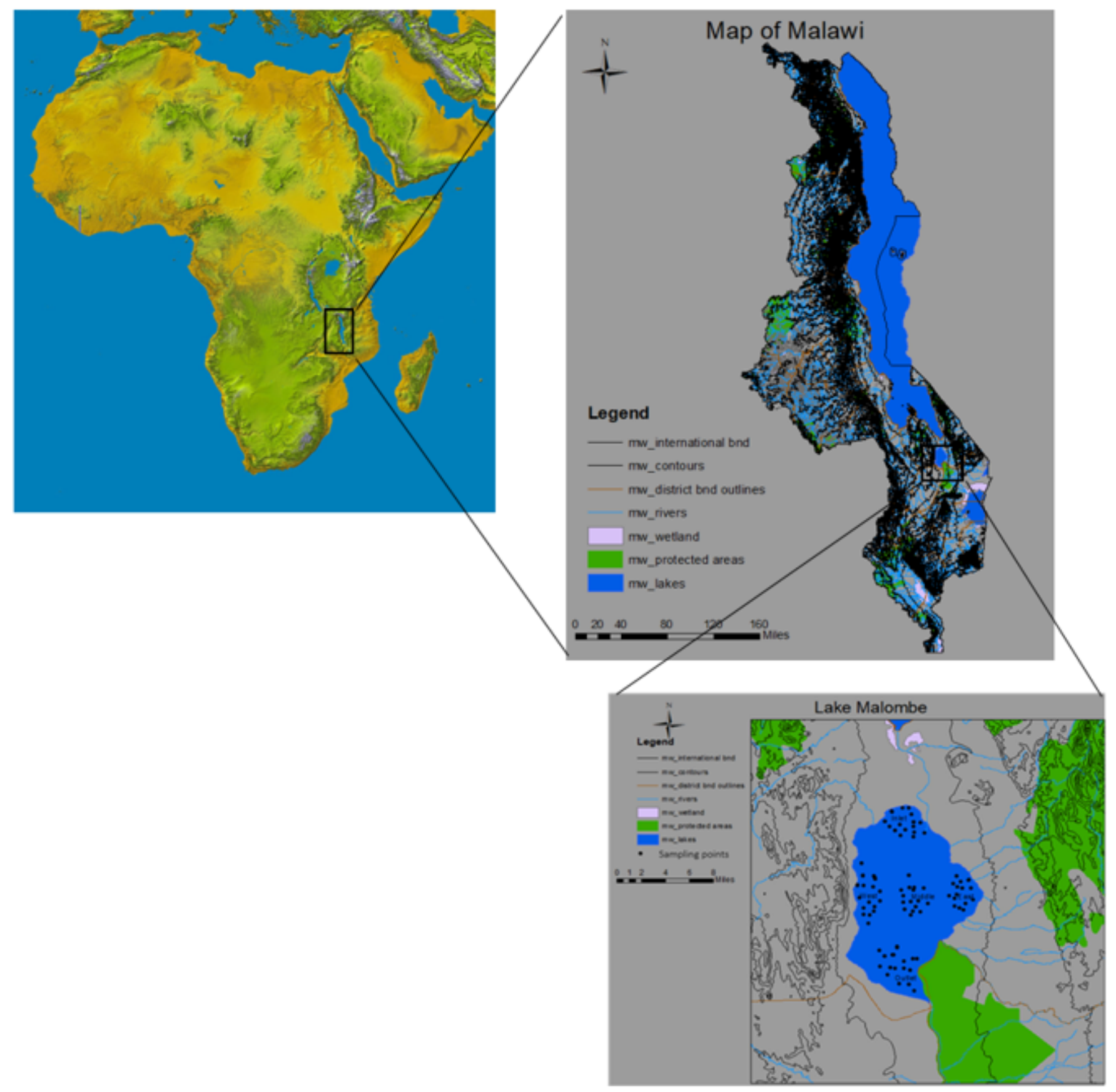

\section{Figure 1}

Map of Lake Malombe. Note: The designations employed and the presentation of the material on this map do not imply the expression of any opinion whatsoever on the part of Research Square concerning the legal status of any country, territory, city or area or of its authorities, or concerning the delimitation of its frontiers or boundaries. This map has been provided by the authors. 

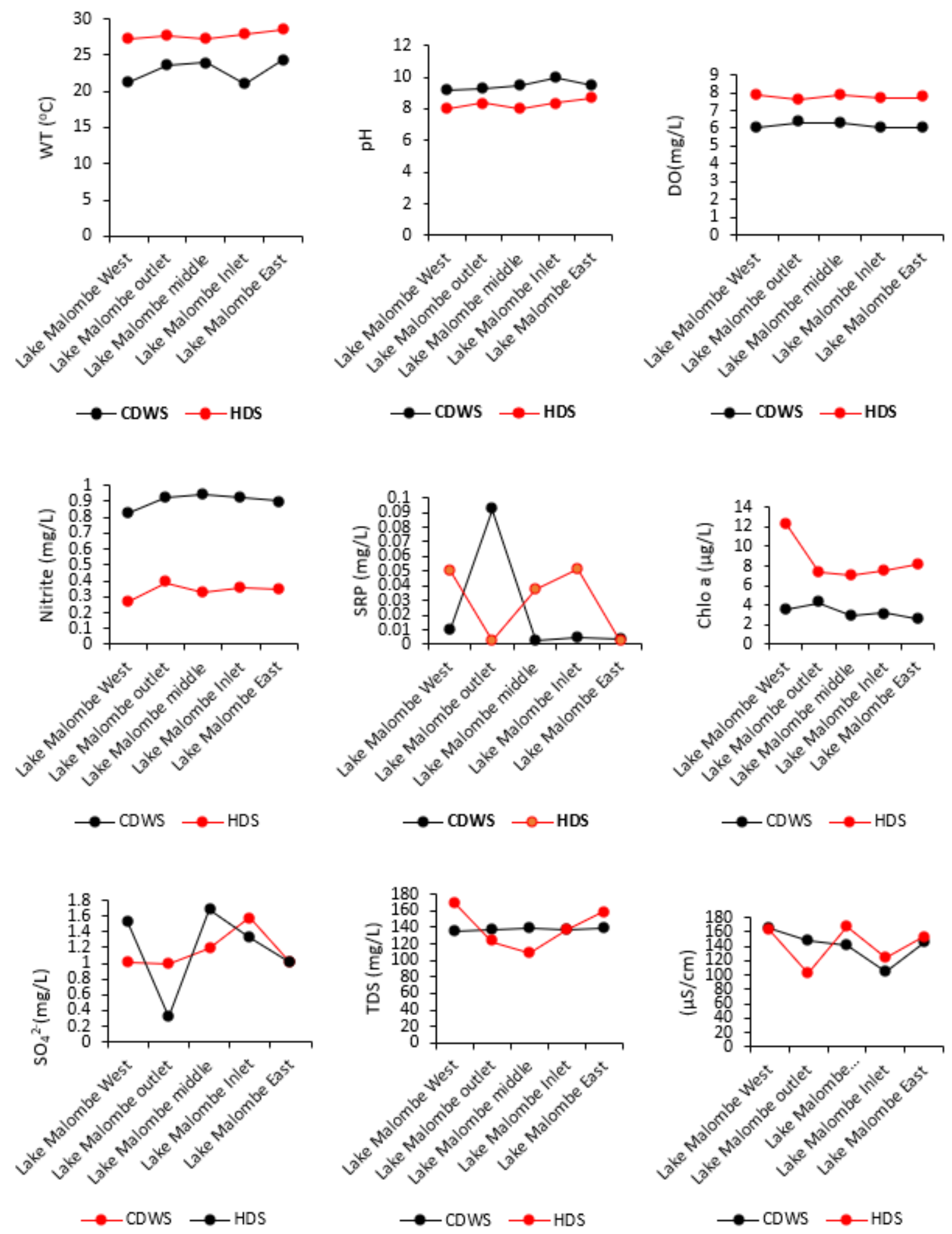

Figure 2

Spatial variation of selected physical-chemical variables and Chlo-a from Lake Malombe in different season 

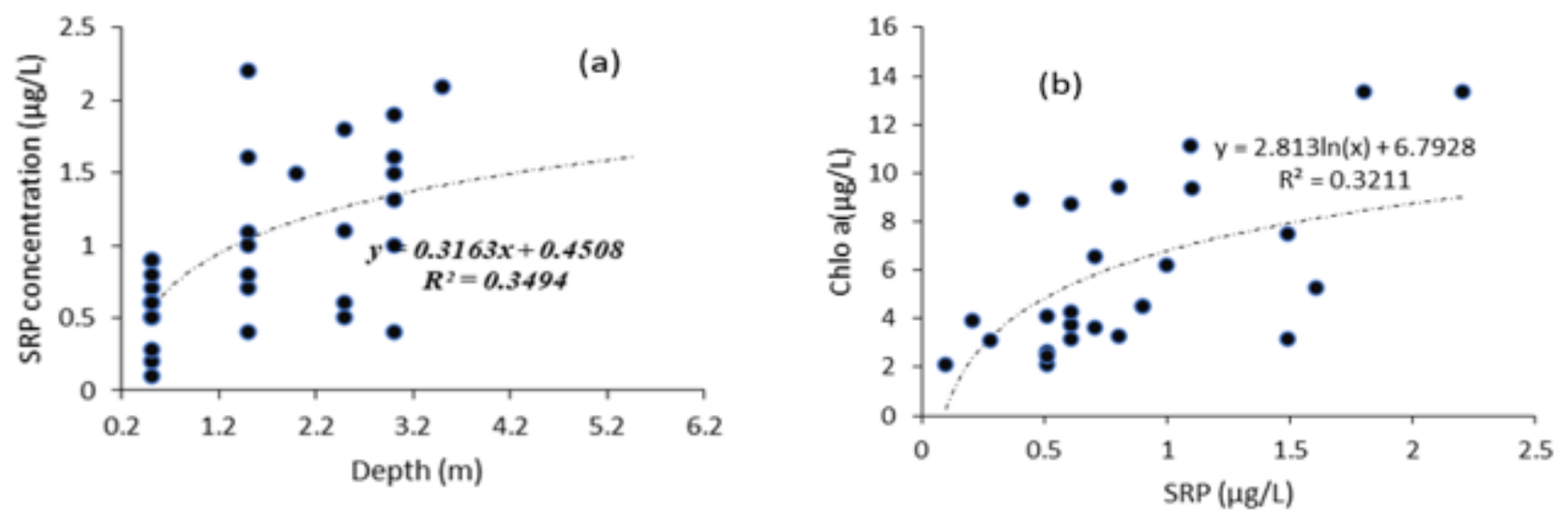

Figure 3

SRP concentration vs sampling depth (a), Chloe a vs SRP concentration (b) 

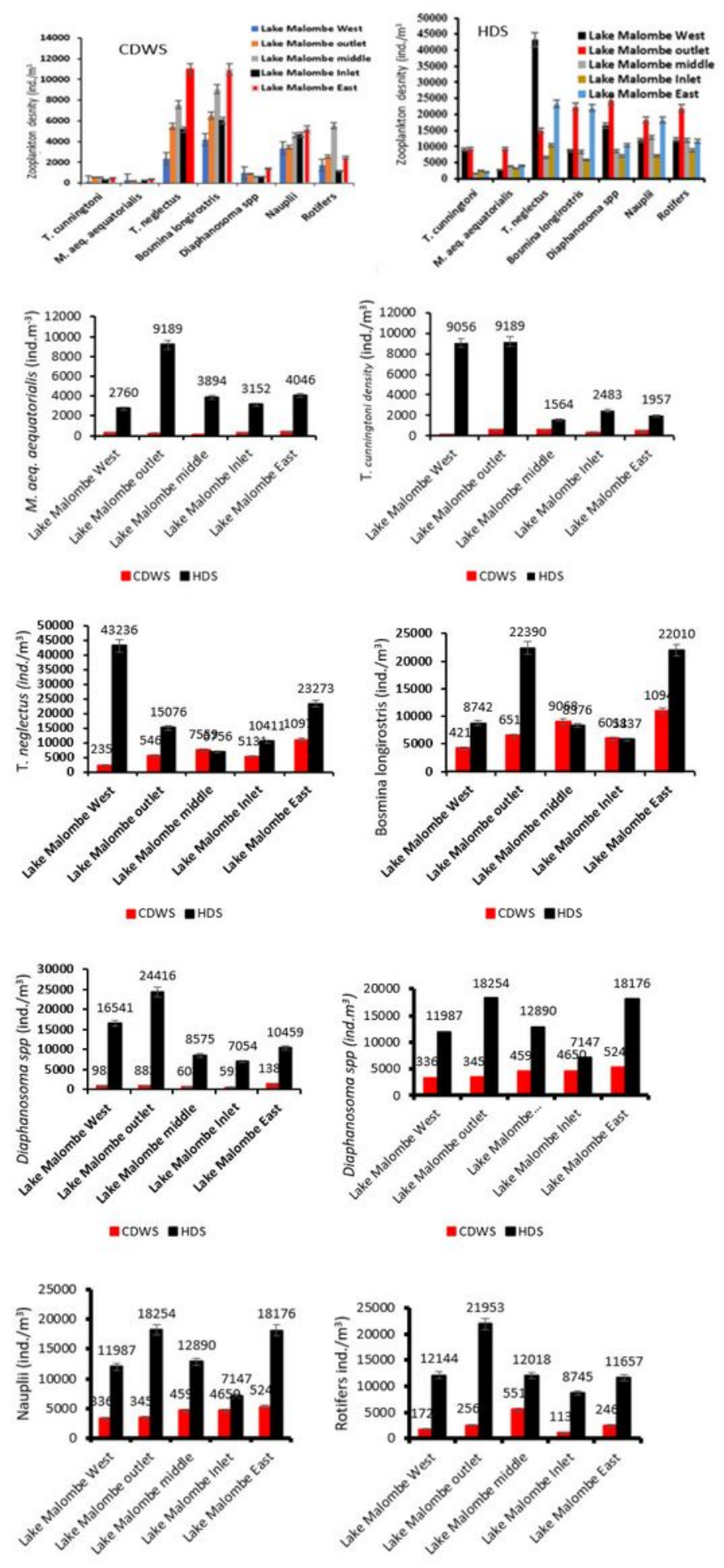

CDWs $\mathrm{HDS}$

a CDWS $\mathrm{HDS}$

Figure 4

Spatial variation of zooplankton density from Lake Malombe in different season 

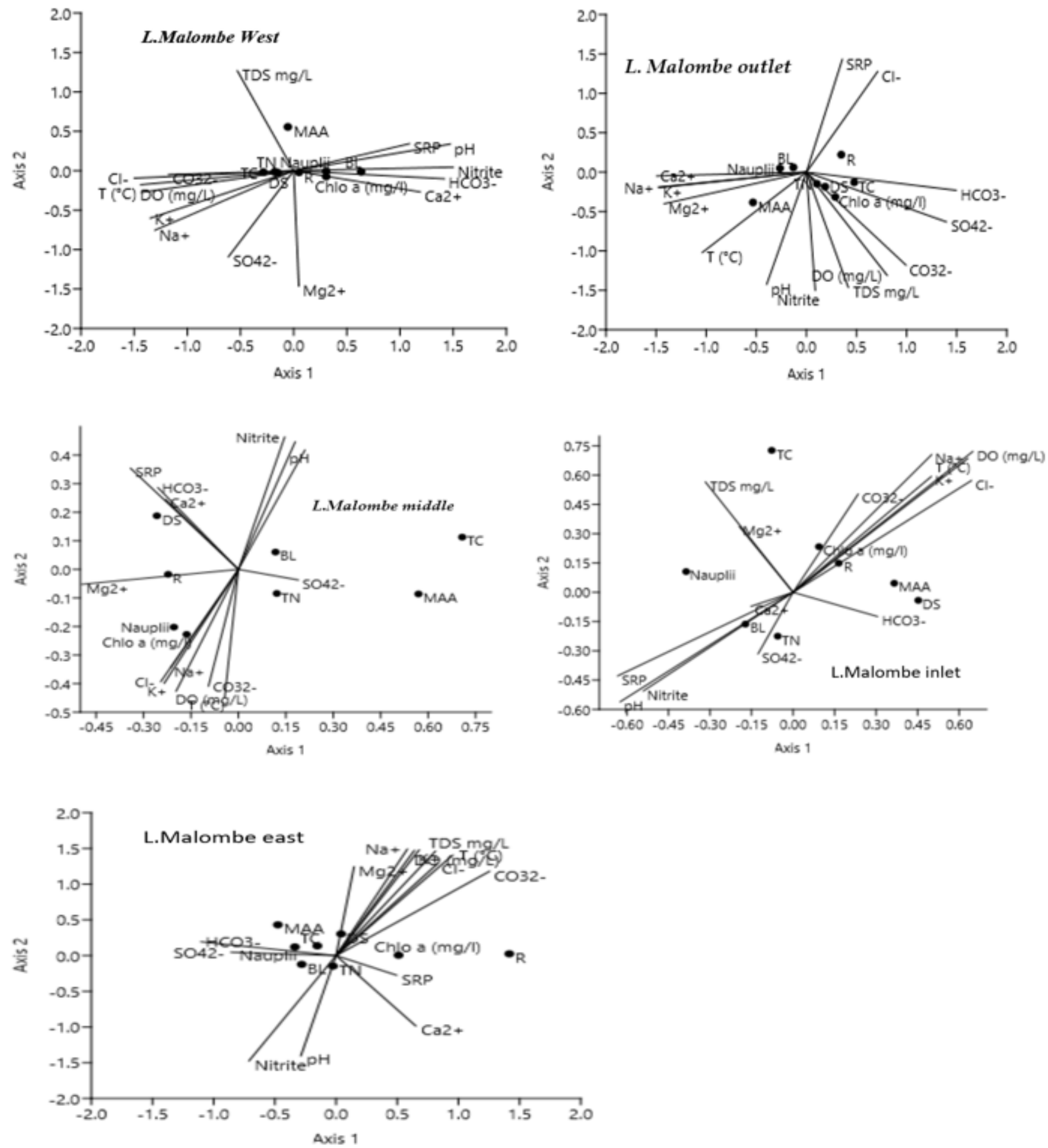

Figure 5

CCA biplot (at Lake Malombe West, outlet, middle, inlet and east) between physical-chemical variables and Chlo-a and zooplankton density. Note: TC means T. cunningtoni, MAA means M. aeq. Aequatorialis, TN means T. neglectus, BL means Bosmina longirostris, DS means Diaphanosoma spp 